\title{
MICROLEAKAGE OF CAVITY CLASS V RESTORED BY COMPOSITE RESIN AND CONVENTIONAL FLOWABLE COMPOSITE RESTORATIONS IN PRIMARY MOLARS CONDITIONED BY ER,CR:YSGG LASER VERSUS CONVENTIONAL METHOD (AN IN VITRO STUDY)
}

\author{
Ayman Abdel Hamid Sabbah*
}

\begin{abstract}
Introduction: In modern operative dentistry in the field of pediatric dentistry Er,Cr:YSGG laser is suitable for cavity preparation in deciduous molars because it have many advantages. Microleakage is one of the major problems that influence the longevity for the resin-based dental restorations. The purpose of the current study is comparing the effect of Er,Cr:YSGG laser and conventional conditioning on the microleakage in cavity class $\mathrm{V}$ restored by composite resin and conventional flowable composite in deciduous molars.
\end{abstract}

Materials and methods: A standard class V cavity were prepared at the buccal or lingual surface of forty-eight freshly extracted caries-free human deciduous molars which were divided into 2 groups according to the mode of conditioning: group 1: by using Er,Cr:YSGG laser; group 2: by using conventional conditioning. The samples were subjected to thermocycling and dying step.

Results: Laser conditioning showed statistically significantly lower mean microleakage scores than conventional technique (P-value $<0.001)$ and ( $\mathrm{P}$-value $=0.001)$, respectively. There was no statistically significant difference between mean microleakage scores of the two composite types $(\mathrm{P}$-value $=0.054)$ and $(\mathrm{P}$-value $=0.096)$, respectively.

Conclusion: Conditioning by Er,Cr:YSGG Laser is better than conventional method as regards microleakage and no significant difference between composite resin and conventional flowable composite clinically.

KEY WORDS: Microleakage, Er,Cr:YSGG laser, Composite resin, Conventional Flowable Composite.

\footnotetext{
* Assistant Professor, Pediatric Dentistry and Orthodontics, Faculty of Dentistry, MIU, Cairo.
} 


\section{INTRODUCTION}

In pediatric dentistry the recent operative techniques have directed to minimal invasive approach, which focus on maximum conservation of tooth structures during management of dental caries. The policy of the American Academy of Pediatric Dentistry (AAPD) stated that when treating hard tissues in children lasers can be an alternative method ${ }^{(1,2)}$. The Erbium, Chromium: Yttrium Scandium Gallium Garnet (Er,Cr:YSGG) laser has been widely used in dentistry ${ }^{(3)}$ as it has many advantages unlike the conventional dental drill, like cutting in hard tissue without contacting the tooth, so doesn't liberate vibrations and noise and in turns the pain are minimal ${ }^{(1)}$, because in most cases, it eliminates the usage of local anesthesia injections ${ }^{(3-6)}$, thus considered a good choice for anxious patients ${ }^{(7)}$. Laser has the capability of removing the smear layer and opening the dentinal tubules ${ }^{(3,8-11)}$, and some authors, stated that laser can eliminate the need for acid etching procedure ${ }^{(3,12,13)}$ while, others stated that to achieve good adhesion with tooth structure combination of laser with acid etching is recommended ${ }^{(3,14)}$. In restorative procedures in pediatric dentistry ${ }^{(15)} \mathrm{Er}, \mathrm{Cr}$ :YSGG laser at $2.78 \mu \mathrm{m}$ is suitable for cavity preparation due to its high absorption water and hydroxyapatite ${ }^{(7,16)}$, so in primary teeth it irradiates the dentin with the least thermal effects on the surrounding ${ }^{(8)}$ and more over it is considered a minimal invasive technique, providing more protection of the dental tissues integrity, which coincide with modern approach of restorative dentistry ${ }^{(15)}$.

Microleakage created by polymerization shrinkage of resin-based dental restorations is considered a major concern for the clinical durability ${ }^{(17-19)}$. Microleakage has wide clinical symptoms, for example postoperative hypersensitivity, marginal discoloration, bonding failure causing dislodgement of the restoration, and Bacterial marginal leakage which may results in recurrent caries and pulpal irritation, which may become irreversible in some cases ${ }^{(20,21)}$. Although many improvements have been done on adhesive systems, but they do not totally eliminate microleakage. The use of conventional diamond burs, during cavity preparation creates a smear layer which consists of debris of organic and nonorganic material on the cavity surface and may leads to microleakage of resin-based restorations ${ }^{(17,22)}$, moreover although laser techniques are not associated with the formation of smear layer, they may cause changes of the dental tissues structure with and increase the risk of microleakage ${ }^{(17,23,24)}$.

Some studies concluded that improvement in adhesion and decrease in microleakage was founded with laser irradiation ${ }^{(1,25,26)}$. Many studies have investigated microleakage of composite restorations after the lasers application focused mainly on permanent ${ }^{(1,27-28)}$, since, primary teeth have many structural and morphological differences than permanent, hence in most occasions the results from studies on permanent teeth cannot be applied on primary teeth, furthermore, few studies are conducted to evaluate the usage of laser devices for cavity preparation in primary teeth prior to adhesive restorations application ${ }^{(17,29)}$.

The aim of this in vitro study was to assess the microleakage of class $\mathrm{V}$ cavities of primary molars prepared by Er,Cr:YSGG laser and restored by two different composite resin restorative materials. The null hypothesis of this study was that there is no significant difference in microleakage between class $\mathrm{V}$ cavities of primary molars restored with composite resin restorations and those restored with flowable composite restorations.

\section{MATERIALS AND METHODS}

Forty-Eight human unidentified deciduous molars with at least intact one surface buccal or lingual that exfoliated either due to physiologic reason or which are indicated for extraction. Teeth with caries on both buccal and/or lingual surfaces, 
fractured crown due to extraction, hypoplastic, hypocalcified and of any developmental anomaly was rejected. The teeth were washed under running water, cleaned of residual tissue and debris, then autoclaved and stored in distilled water at $4{ }^{\circ} \mathrm{C}$ for not more than one week ${ }^{(30,31)}$. Forty-Eight teeth were divided randomly into 2 groups according to the mode of conditioning: group 1: Er,Cr:YSGG laser and group 2: conventional conditioner and each group was further divided into 2 subgroups according to the adhesive restorative material.

\section{Sample Preparation}

A standard class $\mathrm{V}$ cavity were prepared at the buccal or lingual surface of each tooth by using Er,Cr:YSGG laser (Waterlase iPlus, Biolase; Irvine, CA,USA) using a Waterlase iplus Gold handpiece and a MGG6 tapered sapphire tip having a fiber core diameter of $600 \mu \mathrm{m}$ till yellow dentin was seen. The laser settings were $6 \mathrm{~W}$ (peak power), frequency $15 \mathrm{~Hz}$, air pressure $60 \%$, and water pressure $80 \%$, used in noncontact mode with distance of $2 \mathrm{~mm}$ which were controlled by the aid of marked ruler, where the occlusal margin was in enamel and the gingival margin was on cementoenamel junction. The dimension of the cavity was $2 \mathrm{~mm}$ in height, width, and depth which was adjusted by using a premarked periodontal probe.

\section{Conditioning of the enamel and dentin}

In group 1 (24 teeth), conditioning with Er,Cr:YSGG laser (Waterlase iPlus, Biolase; Irvine, CA,USA) using a Waterlase iplus Gold handpiece and a MGG6 tapered sapphire tip having a fiber core diameter of $600 \mu \mathrm{m}$. The laser settings were $4.5 \mathrm{~W}$ (peak power), frequency $50 \mathrm{~Hz}$, air pressure $60 \%$, and water pressure $80 \%$, used in noncontact mode.

In group 2 (24 teeth), Dentin conditioner (GC Corporation, Tokyo, Japan) was applied on cavity surfaces, left for 20 seconds, then washed and dried slightly with a gentle stream of oil-free air to avoid desiccation.

\section{Restorative Material Application}

Group 1 (24 teeth) was subdivided into subgroup 1 containing 12 teeth, where two layers of bonding agent (Adper single bond, 3MESPE, USA) were applied on the etched surfaces and light cured for 10 seconds with light curing unit (POLI LED Curing light, Faro, Italy) followed by application of composite resin (Z-250, 3M/ESPE) that was prepared according to the instructions of the manufacturer, and packed in the cavity then light curing for 20 seconds with light curing unit (POLI LED Curing light, Faro, Italy) and subgroup 2 containing 12 teeth, two layers of bonding agent (Adper single bond, 3MESPE, USA) were applied on the etched surfaces and light cured for 10 seconds with light curing unit (POLI LED Curing light, Faro, Italy), followed by application of conventional flowable composite (3M/Dental Product, USA) that was prepared according to the instructions of the manufacturer, and packed in the cavity then light curing for 20 seconds with light curing unit (POLI LED Curing light, Faro, Italy).

Group 2 (24 teeth) was subdivided into subgroup 1 containing 12 teeth, where two layers of bonding agent (Adper single bond, 3MESPE, USA) were applied on the etched surfaces and light cured for 10 seconds with light curing unit (POLI LED Curing light, Faro, Italy), followed by application of composite resin (Z-250, 3M/ESPE) that was prepared according to the instructions of the manufacturer, and packed in the cavity then light curing for 20 seconds with light curing unit (POLI LED Curing light, Faro, Italy) and subgroup 2 containing 12 teeth, two layers of bonding agent (Adper single bond, 3MESPE, USA) were applied on the etched surfaces and light cured for 10 seconds with light curing unit (POLI LED Curing light, Faro, Italy), followed by application of conventional flowable composite (3M/Dental Product, USA) that was prepared according to the instructions of the manufacturer, and packed in the cavity then light curing for 20 seconds with light curing unit (POLI LED Curing light, Faro, Italy). 
Finishing and polishing of all the restorations were then done by finishing burs.

\section{Microleakage Test}

Restored samples were thermocycled for 700 cycles, where each cycle consists of a water bath at $5^{\circ} \mathrm{C} \pm 2^{\circ} \mathrm{C}$ and $55^{\circ} \mathrm{C}$ with a 60 -second of dwell time in each bath. By the aid of absorbent paper, the samples were superficially dried then sealed with 2 coats of nail varnish, and a window of $1 \mathrm{~mm}$ around the margins of the cavity restoration were left. To prevent penetration of the dye to the apical region, it was also sealed by epoxy glue. The samples were immersed in $2 \%$ buffered methylene blue solution for 4 hours at $\mathrm{pH} 7$, after which rinsing all samples by tap water for 5 minutes were done and dried with absorbent paper. Sectioning of each restoration was done by cutting it in the buccolingual direction and through the center of restoration by using low-speed and water-cooled diamond disc (KG Sorenesen). Scoring the degree of the dye penetration was done by the aid of a light stereoscope (Meiji 2000, Saitama, Japan) at X30 magnification 29) on a 4 grade scale as follows ${ }^{32}$ :

a) Score $0=$ no dye penetration

b) Score $1=$ dye penetration along the interface to one third of the cavity depth c) Score $2=$ dye penetration along the interface to two thirds of the cavity wall depth

d) Score $3=$ dye penetration to but not along the axial wall; and e. score $4=$ dye penetration up to and along the axial wall.

\section{Statistical Analysis}

Data were presented as mean and standard deviation values. Student's t-test was used to compare between the two composite type as well as the two conditioning techniques. The significance level was set at $\mathrm{P} \leq 0.05$. Statistical analysis was performed with IBM SPSS Statistics for Windows, Version 23.0. Armonk, NY: IBM Corp.

\section{RESULTS}

Comparison between the two condition techniques revealed that Laser showed statistically significantly lower mean microleakage scores than conventional technique $(P$-value $=0.001)$ and $(P$-value $=0.002)$, respectively.

Comparison between the two composite types revealed that there was no statistically significant difference between mean microleakage scores of the two composite types $(P$-value $=0.057)$ and $(P$-value $=0.108)$, respectively.

TABLE (1) The mean, standard deviation values and results of Student's t-test for comparison between microleakage scores of the two composite types as well as the two conditioning techniques

\begin{tabular}{|c|c|c|c|c|c|}
\hline \multirow{2}{*}{ Conditioning technique } & \multicolumn{2}{|c|}{$\begin{array}{c}\text { Flowable composite } \\
(\mathbf{n}=\mathbf{1 0})\end{array}$} & \multicolumn{2}{|c|}{$\begin{array}{c}\text { Composite } \\
(\mathbf{n}=\mathbf{1 0})\end{array}$} & \multirow{2}{*}{$\begin{array}{c}\text { P-value (Between } \\
\text { composite types) }\end{array}$} \\
\cline { 2 - 6 } & Mean & SD & Mean & SD & 0.054 \\
\hline Laser & 1.1 & 0.32 & 1.5 & 0.53 & 0.096 \\
\hline Conventional & 2.1 & 0.57 & 2.6 & 0.7 & \\
\hline $\boldsymbol{P}$-value (Between techniques) & \multicolumn{2}{|c|}{$<0.001 *$} & \multicolumn{2}{|c|}{$0.001^{*}$} & \\
\hline
\end{tabular}

*: Significant at $P \leq 0.05$ 


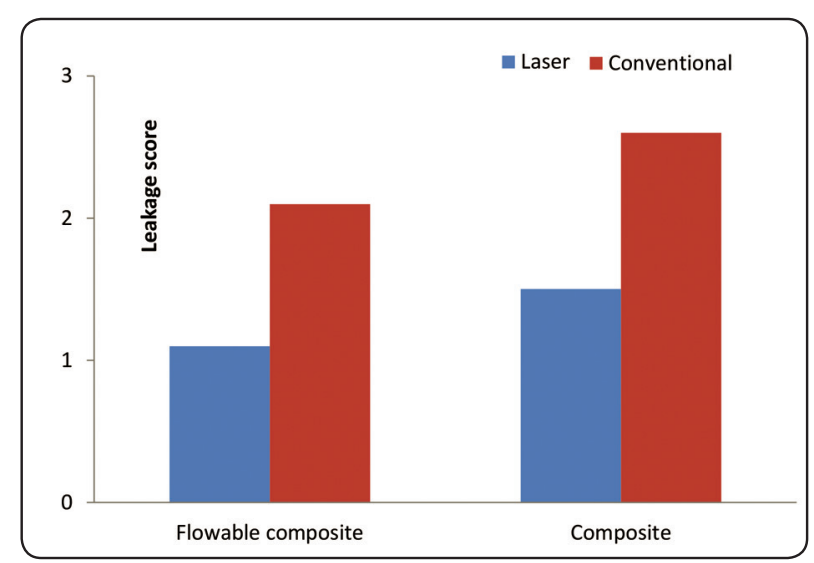

Fig. (1) Bar chart representing mean microleakage scores

\section{DISCUSSION}

Microleakage is one of the most regularly faced issues specially, in class $\mathrm{V}$ restorations. This may be attributed to the differences between coefficient of thermal expansion of the restorative materials and the dental tissues ${ }^{(16,33)}$, or may be due to shrinkage caused by factors of cavity configuration, which results in formation of gap at the tooth-restoration interface $^{(16,34)}$.

Many methods which are either qualitative and quantitative have been used to determine microleakage, which involve the use of electrochemical technique, reversible radioactive adsorption, scanning electron microscope, nanotechnology and dyes. Dye penetration method was used in this study to estimate microleakage, as it's used on a wide scale and preferred generally because it is easily obtained, non-toxic and inexpensive ${ }^{(1,35)}$.

The formation of hybrid layer, dentin collagen intermixture and suffused components of the adhesive system, determine the clinical outcome of bonded restorations to tooth structure $^{(3,36)}$, which ideally must be big enough to permit a steady interlocking between the adhesive resin and the exposed collagen fibers. Furthermore, the demineralized area must not be highly deep, which may cause the primer and adhesive resin not to inflow through the whole exposed fibers and attach them entirely ${ }^{(3)}$, resulting in lower microleakage, preferred and long standing restorations ${ }^{(3,37-39)}$.

Acid etch is a critical stage during adhesive restorations application, though Usumez et al. ${ }^{(3,40)}$, Basaran et al. ${ }^{(3,41)}$, and Sung et al. ${ }^{(3,11)}$ stated that there were no statistical differences between laser and acid etching, which were in contrary with the results of this study, where laser showed statistically significantly lower mean microleakage scores than conventional technique. Etching by Er,Cr:YSGG lasers which possess a wavelength of $2.78 \mu \mathrm{m}$ can produce more irregular surfaces, when it's the hydroxyl ions contained in the hydroxyapatite absorbs it, that results in a little elevation in the outer layer temperature, without causing damage to the adjacent tissues ${ }^{(1,42)}$.

Dentin gives a potent thermo-mechanical interaction with Er,Cr:YSGG laser irradiation due to its high collagen matrix and water content that causes the more absorption of the energy of laser by the inter-tubular dentin results in unexpected fast increase in temperature and evaporation of water, and the elevation of pressure causes a group of mini explosions with ejection of tissue particles, and lead to presence of tiny circular depression-like cavities in the surfaces treated ${ }^{(1,43)}$, more over absence of smear layer in lased tooth surfaces leads to better adhesion of restorative materials with enamel and dentin reducing microleakage, because smear layer has a low surface energy, which intervene with bonding to tooth surfaces ${ }^{(1,44-46)}$.

On the contrary to the findings of this study, De Munck et al. ${ }^{(47)}$ stated that the cavities prepared by laser showed low reception to adhesive restorations than cavities prepared by conventional bur. Several studies revealed that laser irradiation can passively affect the interface between dentin and adhesive system, restraining the formation of the hybrid layer $^{(3,48,49)}$. Other studies suggested applying acid etching following cavity preparation using laser irradiation $^{(3,50)}$. 
In a study done by Subramaniam \& Pandey (2016) increased microleakage was found after conventional etching by phosphoric acid is used because it eliminates smear layer and expose enamel prism sheaths and dentinal tubules ${ }^{(1,8)}$, and most probably due to absence of particular etching patterns in deciduous teeth with only surface roughness and no entire dentin demineralization ${ }^{(1,51-53)}$, which may support the findings of the current study.

\section{CONCLUSION}

The following can be concluded regarding the findings of the current laboratory study:

1. Conditioning by Er,Cr:YSGG Laser is better than Conventional method as regards microleakage.

2. No significant difference between composite resin and conventional flowable composite concerning microleakage.

\section{REFERENCES}

1. Subramaniam P, Pandey A. Assessment of Microleakage of a Composite Resin Restoration in Primary Teeth Following Class III Cavity Preparation Using Er, Cr: YSGG laser: An in Vitro Study. J Lasers Med Sci. 2016; 7:172-6.

2. American Academy of Pediatric Dentistry. Policy on the use of Lasers for pediatric dental patients. Pediatr Dent. $2014 ; 36: 75-7$.

3. Öznurhan F, Ölmez A. Nanoleakage in primary teeth prepared by laser irradiation or bur. Lasers Med Sci. 2013; 28:1099-1105.

4. Genovese MD, Olivi G. Laser in paediatric dentistry: patient acceptance of hard and soft tissue therapy. Eur J Paediatr Dent. 2008; 9:13-7.

5. Hadley J, Young DA, Eversole LR, Gornbein JA. A laser powered hydrokinetic system for caries removal and cavity preparation. J Am Dent Assoc. 2000; 131:777-85.

6. Hossain M, Nakamura Y, Tamaki Y, Yamada Y, Murakami Y, Matsumoto K. Atomic analysis and Knoop hardness measurement of the cavity floor prepared by Er, Cr:YSGG laser irradiation in vitro. J Oral Rehabil. 2003; 30:515-21.
7. Jacobson B, Asgari A. Restorative dentistry for children using a hard tissue laser. Alpha Omegan. 2008; 101:133-9.

8. Hossain M, Nakamura Y, Yamada Y, Murakami Y, Matsumoto K. Compositional and structural changes of human dentin following caries removal by Er, Cr:YSGG laser irradiation in primary teeth. J Clin Pediatr Dent. 2002; 26:377-82.

9. Jacboson B, Berger J, Kravitz R, Ko J. Laser pediatric class II composites utilizing noanesthesia. J ClinPediatrDent. 2004; 28:99-101.

10. Jacboson B, Berger J, Kravitz R, Patel P. Laser pediatric crowns performed without anesthesia: a contemporary technique. J Clin Pediatr Dent. 2003; 28:11-2.

11. Sung EC, Chenard T, Caputo AA, Amodeo M, Chung EM, Rizoiu IM. Composite resin bond strength to primary dentin prepared with Er, Cr:YSSG laser. J Clin Pediatr Dent. 2005; 30:45-9.

12. Gutknecht N, Apel C, Schafer C, Lampert F. Microleakage of composite fillings in Er, Cr:YSGG laser-prepared class II cavities. Lasers Surg Med. 2001; 28:371-4.

13. Hossain M, Kimura Y, Nakamura Y, Yamada Y, Kinoshita JI, Matsumoto K. A study on acquired acid resistance of enamel and dentin irradiated by Er, Cr:YSGG laser. J Clin Laser Med Surg. 2001; 19:159-63.

14. Ergucu Z, Celik EU, Turkun M. Microleakage study of different adhesive systems in class $\mathrm{V}$ cavities prepared by Er,Cr: YSGG laser and bur preparation. Gen Dent. 2007; $55: 27-32$

15. Sanhadji El Haddar Y, Cetik S, Bahrami B, Atash R. A Comparative Study of Microleakage on Dental Surfaces Bonded with Three Self-Etch Adhesive Systems Treated with the Er:YAG Laser and Bur. BioMed Res Inter. 2016; 2509757.

16. Sertac Peker, Figen Eren Giray, Basak Durmus, Nural Bekiroglu, Betül Kargül \& Mutlu Özcan: Microleakage in class $\mathrm{V}$ cavities prepared using conventional method versus Er:YAG laser restored with glass ionomer cement or resin composite. J Adhesion Sci and Tech. 2016; 2016:1220471.

17. Kalyoncu IO, Eren-Giray F, Huroglu N, Egil E, Tanboga I. Microleakage of Different Adhesive Systems in Primary Molars Prepared by Er: YAG Laser or bur. Niger J Clin Pract. 2018; 2018:21:242-7.

18. Baygin O, Korkmaz FM, Arslan I. Effects of different types of adhesive systems on the microleakage of compomer 
restorations in Class V cavities prepared by Er,Cr:YSGG laser in primary teeth. Dent Mater J. 2012; 31:206-14.

19. Guéders A, Geerts S. Relationship between operator skill and in vitro microleakage of different adhesive systems in Class V restorations. ISRN Dent. 2011; 2011:285624.

20. Rasmy AHM, Harhash TA, Ghali RMS, El Maghraby EMF, El Rouby DH. Comparative study between laser and conventional techniques for class $\mathrm{V}$ cavity preparation in gamma-irradiated teeth (in vitro study). J Appl Oral Sci. 2017; 25:657-65.

21. González-Cabezas C, Li Y, Gregory RL, Stookey GK. Distribution of cariogenic bacteria in carious lesions around tooth-colored restoration. Am J Dent. 2002;15 :248-51.

22. Malekipour MR, Shirani F, Tahmourespour S. The effect of cutting efficacy of diamond burs on microleakage of class $\mathrm{v}$ resin composite restorations using total etch and self-etch adhesive systems. J Dent (Tehran). 2010; 7:218-25.

23. Hossain M, Nakamura Y, Yamada Y, Kimura Y, Matsumoto $\mathrm{N}$, Matsumoto K. Effects of Er,Cr:YSGG laser irradiation in human enamel and dentin: ablation and morphological studies. J Clin Laser Med Surg 1999; 17:155-9.

24. Borsatto MC, Corona SA, Chinelatti MA, Ramos RP, de Sa Rocha RA, Pecora JD et al. Comparison of marginal microleakage of flowable composite restorations in primary molars prepared by high-speed carbide bur, Er:YAG laser, and air abrasion. J Dent Child (Chic). 2006; 73:122-6.

25. Palma Dibb RG, Milori Corona SA, Borsatto MC, Ferreira KC, Pereira Ramos R, DjalmaPécora J. Assessing microleakage on class $\mathrm{V}$ composite resin restorations after Er:YAG laser preparation varying the adhesive systems. J Clin Laser Med Surg. 2002; 20:129-33.

26. Esteves-Oliveira M, Zezell DM, Apel C, et al. Bond strength of self-etching primer to bur -cut, Er, Cr:YSGG and Er:YAG lased dental surfaces. Photomed Laser Surg. 2007; 25:373-80.

27. Shahabi S, Ebrahimpour L, Walsh LJ. Microleakage of composite resin restorations in cervical cavities prepared by Er,Cr:YSGG laser radiation. Aust Dent J. 2008; 53:172-75.

28. Marotti J, Geraldo-Martins VR, Bello-Silva MS, de Paula Eduardo C, Apel C, Gutknecht N. Influence of etching with erbium, chromium:yttrium-scandium-gallium-garnetlaser on microleakage of class $\mathrm{V}$ restoration. Lasers Med Sci. 2010; 25:325-29.
29. Bahrololoomi Z, Heydari E. Assessment of tooth preparation via Er:YAG laser and bur on microleakage of dentin adhesives. J Dent (Tehran) 2014; 11:172-8.

30. Scatena C, Torres CP, Gomes-Silva JM, Contente MM, Pécora JD, Palma-Dibb RG, et al. Shear strength of the bond to primary dentin: Influence of Er: YAG laser irradiation distance. Lasers Med Sci. 2011; 26:293-7.

31. Bahrololoomi Z, Ghafourifard R. Shear Bond Strength of Primary Teeth Dentin Irradiated with Different Erbiumdoped Yttrium Aluminium Garnet Laser Energies and Scanning Electron Microscope Study of Dentin Morphology. J Inter Oral Health. 2016; 8:943-7.

32. Ghandehari M, Mighani G, Shahabi S, Chiniforush N, Shirmohammadi Z. Comparison of Microleakage of Glass Ionomer Restoration in Primary Teeth Prepared by Er: YAG Laser and the Conventional Method. J Dent. Tehran Uni Med Sci. 2012; 9:215-20.

33. Jokstad A Secondary caries and microleakage. Dent. Mater. 2015 Epub.

34. Francisconi LF, Scaffa PM, de Barros VR, et al. Glass ionomer cements and their role in the restoration of noncarious cervical lesions. J Appl Oral Sci. 2009; 17:364-9.

35. Baygin O, Korkmaz FM, Arslan I. Effects of different types of adhesive systems on the microleakage of compomer restorations in Class V cavities prepared by Er,Cr:YSGG laser in primary teeth. Dent Mater J. 2012; 31:206-14.

36. Oztas N, Olmez A. Effects of one versus two-layer applications of a self-etching adhesive to dentin of primary teeth: a SEM study. J Contemp Dent Pract. 2005; 6:18-25.

37. Hashimoto M, Ohno H, Endo K, Kaga M, Sano H, Oguchi $\mathrm{H}$. The effect of hybrid layer thickness on bond strength: demineralized dentin zone of the hybrid layer. Dent Mater. 2000; 16:406-11.

38. Nakajima M, Ogata M, Okuda M, Tagami J, Sano H, Pashley DH. Bonding to caries-affected dentin using selfetching primers. Am J Dent. 1999; 12:309-14.

39. Perdigao J, May KN Jr, Wilder AD Jr, Lopes M. The effect of depth of dentin demineralization on bond strengths and morphology of the hybrid layer. Oper Dent. 2000; 25 : 186-94.

40. Usumez S, Orhan M, Usumez A. Laser etching of enamel for direct bonding with an Er,Cr:YSGG hydrokinetic laser system. Am J Orthod Dentofacial Orthop. 2002; 122:649-56. 
41. Basaran G, Ozer T, Berk N, Hamamci O. Etching enamel for orthodontics with an erbium, chromium:yttriumscandium-gallium-garnet laser system. Angle Orthod. 2007; 77:117-23.

42. Kohara EK, Hossain M, Kimura Y, Matsumoto K, Inoue M, Sasa R. Morpholgical and microleakage studies of the cavities prepared by Er:YAG laser irradiation in primary teeth. J Clin Laser Med Surg. 2002; 20:141-7.

43. Ramos RP, Chimello DT, Chinelatti MA, Nonaka T, Pécora JD, Palma Dibb RG.Effect of Er:YAG laser on bond strength to dentin of a self-etching primer and two singlebottle adhesive systems. Lasers Surg Med. 2002; 31:164-70.

44. Shahabi S, Chiniforush N, Bahramian H, Monzavi A, Baghalian A, Kharazifard MJ. The effect of erbium family laser on tensile bond strength of composite to dentin in comparison with conventional method. Lasers Med Sci. 2013; 28:139-42.

45. Ekworapoj P, Sidhu SK, McCabe JF. Effect of different power parameters of Er, Cr:YSGG laser on human dentine. Laser Med Sci. 2007; 23:175-82.

46. Gurgan S, Kiremitci A, Cakir FY, Yazici E, Gorucu J, Gutknecht N. Shear bond strength of composite bonded to erbium:yttrium-aluminum-garnet laser-prepared dentin. Lasers Med Sci. 2009; 24:117-22.
47. De Munck J, Van Meerbeek B, Yudhira R, Lambrechts P, Vanherle G. Micro-tensile bond strength of two adhesives to erbium: YAG-lased vs. bur-cut enamel and dentin. Eur J Oral Sci. 2002; $110: 322-9$.

48. Barceleiro Mde O, de Mello JB, de Mello GS, Dias KR, de Miranda MS, Sampaio Filho HR. Hybrid layer thickness and morphology: the influence of cavity preparation with Er:YAG laser. Oper Dent. 2005; 30:304-10.

49. Sassi JF, Chimello DT, Borsatto MC, Corona SA, Pecora JD, Palma-Dibb RG. Comparative study of the dentin/ adhesive systems interface after treatment with Er:YAG laser and acid etching using scanning electron microscope. Lasers Surg Med. 2004; 34 :385-90.

50. Bertrand MF, Hessleyer D, Muller-Bolla M, Nammour S, Rocca JP. Scanning electron microscopic evaluation of resin-dentin interface after Er:YAG laser preparation. Lasers Surg Med. 2004; 35:51-7.

51. Sardella TN, de Castro FL, Sanabe ME, Hebling J. Shortening of primary dentin etching time and its implication on bond strength. J Dent. 2005; 33:355-62.

52. Osorio R, Aguilera FS, Otero PR, et al. Primary dentin etching time, bond strength and ultra-structure characterization of dentin surfaces. J Dent. 2010; 38:222-31.

53. Camps J, Pashley DH. Buffering action of human dentin in vitro. J Adhes Dent. 2000; 2:39-50. 